\title{
A 15-year journey through the land of culture research
}

\author{
$\mathrm{VQH}$ \\ January 1, 2021
}

It has been 15 years since I officially embarked on the journey of culture research, marked by the publication of my book on entrepreneurship in Vietnamese [1]. The book was started out in early 2006.

I have learned a lot about our own cultures, i.e., Vietnamese cultures, as well as the implications and influences of cultures on economic development, corporate sector growth, and a nation's future.

In 2009, the first study on the influence of Confucian cultural values on Vietnamese entrepreneurship was published, making several of my friends raise their eyebrows. Most had thought I would mainly focus on financial engineering, my field of profession as defined by education and job.

This rather abrupt shift has led to many interesting research contributions later on. The three most important to me and my students are:

- Cultural additivity: behavioural insights from the interaction of Confucianism, Buddhism and Taoism in folktales [3]

- Cultural evolution in Vietnam's early 20th century: A Bayesian networks analysis of Hanoi Franco-Chinese house designs [4]

- On how religions could accidentally incite lies and violence: Folktales as a cultural transmitter [5]

These three works [3-5] spanned three years (2018-2020). They represent our strong commitment to implementing the Bayesian MCMC method in interdisciplinary social research studies.

Given their scope and nature, we expect them to have a long lifecycle after their publication, perhaps many years more into the future.

Apart from the above studies, which directly discussed the cultural aspects of the research subjects, many important publications deal with the cultures from different angles, particularly the view of science policy. And these include the following singleauthored papers:

- Vietnam's political economy: A discussion on the 1986-2016 period [6] 
- Be rich or don't be sick: estimating Vietnamese patients' risk of falling into destitution [7]

- Impacts of geographical locations and sociocultural traits on the Vietnamese entrepreneurship [8]

- Survey data on Vietnamese propensity to attend periodic general health examinations [9]

- Open data, open review and open dialogue in making social sciences plausible [10]

- The (ir)rational consideration of the cost of science in transition economies [11]

- Breaking barriers in publishing demands a proactive attitude [12]

- Reform retractions to make them more transparent [13]

It is now safe to say that the land of culture research has opened up a vast uncharted region of opportunities for me to explore, a treasure trove, indeed.

There will be many more problems for social science researchers to investigate, given the changing landscape of social research unfolded by the COVID-19 pandemic in the years to come.

The last words of this short summary paper will be devoted to the most recent principle proposed in [14]. I expect the new principle to exert its influence on the academic realm of sustainability science and sustainable development upon the arrivals of new evidence that the old mechanisms - which has, thus far, shown a lot more tolerance to environmental-destructive behaviors-have failed miserably.

To me, the facts about the environmental breakdown from the past two decades have been quite subversive. The newly proposed principle has just reinstated the implications these facts and findings have brought to humankind. Perhaps by now, it is no longer surprising that the principle deals with the cultural aspects of the environmentprotecting mission.

\section{References}

[1] Hoàng VQ. (2007). Văn minh làm giàu \& nguồn gốc của cải. Nxb Chính trị quốc gia, Hà Nội.

[2] Vuong QH, Tran TD. (2009). The Cultural Dimensions of the Vietnamese Private Entrepreneurship. The IUP Journal of Entrepreneurship Development, 6(3/4), 54-78.

[3] Vuong QH, Bui QK, La VP, Vuong TT, et al. (2018). Cultural additivity: behavioural insights from the interaction of Confucianism, Buddhism and Taoism in folktales. Palgrave Communications, 4(1), 143. 
[4] Vuong QH, Bui QK, La VP, Vuong TT, et al. (2019). Cultural evolution in Vietnam's early 20th century: A Bayesian networks analysis of Hanoi Franco-Chinese house designs. Social Sciences \& Humanities Open, 1(1), 100001.

[5] Vuong QH, Ho MT, Nguyen HKT, Vuong TT, et al. (2020). On how religions could accidentally incite lies and violence: Folktales as a cultural transmitter. Palgrave Communications, 6(1), 82.

[6] Vuong QH. (2014). Vietnam's Political Economy: A Discussion on the 1986-2016 Period. CEB Working Papers Series, N¹4-010, Université Libre de Bruxelles, Brussels, Belgium.

[7] Vuong QH. (2015). Be rich or don't be sick: estimating Vietnamese patients' risk of falling into destitution. SpringerPlus, 4(1), 529.

[8] Vuong QH. (2016). Impacts of geographical locations and sociocultural traits on the Vietnamese entrepreneurship. SpringerPlus, 5(1), 1189.

[9] Vuong QH. (2017). Survey data on Vietnamese propensity to attend periodic general health examinations. Scientific Data, 4(1), 170142.

[10] Vuong QH. (2017). Open data, open review and open dialogue in making social sciences plausible. Nature: Scientific Data Updates (December 12). Retrieved from: https:// go.nature.com/2QdnUrW

[11] Vuong QH. (2018). The (ir)rational consideration of the cost of science in transition economies. Nature Human Behaviour, 2(1), 5.

[12] Vuong QH. (2019). Breaking barriers in publishing demands a proactive attitude. Nature Human Behaviour, 3(10), 1034.

[13] Vuong QH. (2020). Reform retractions to make them more transparent. Nature, 582(7811), 149.

[14] Vuong QH. (2020). The semiconducting principle of monetary and environmental values exchange. OSF Preprints (October 24); doi:10.31219/osf.io/nv3yz. 